\title{
Explosive Effectiveness Capability (ExEC)
}

\author{
G. Nakafuji, L. Daily, J. Leake
}

\section{July 26, 2000}

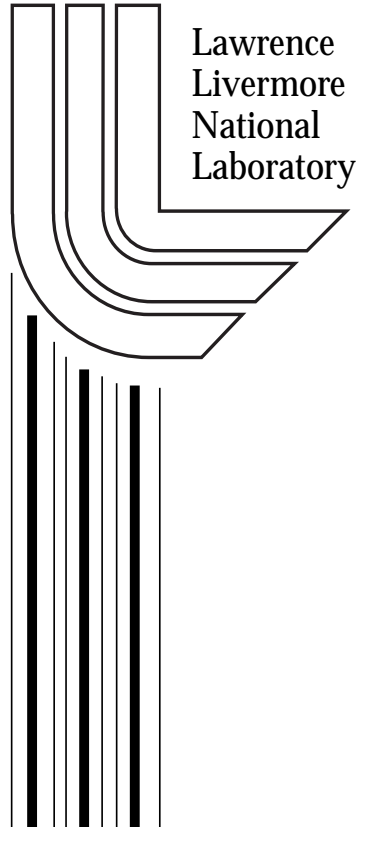




\section{DISCLAIMER}

This document was prepared as an account of work sponsored by an agency of the United States Government. Neither the United States Government nor the University of California nor any of their employees, makes any warranty, express or implied, or assumes any legal liability or responsibility for the accuracy, completeness, or usefulness of any information, apparatus, product, or process disclosed, or represents that its use would not infringe privately owned rights. Reference herein to any specific commercial product, process, or service by trade name, trademark, manufacturer, or otherwise, does not necessarily constitute or imply its endorsement, recommendation, or favoring by the United States Government or the University of California. The views and opinions of authors expressed herein do not necessarily state or reflect those of the United States Government or the University of California, and shall not be used for advertising or product endorsement purposes.

This work was performed under the auspices of the U. S. Department of Energy by the University of California, Lawrence Livermore National Laboratory under Contract No. W-7405-Eng-48.

This report has been reproduced directly from the best available copy.

Available to DOE and DOE contractors from the

Office of Scientific and Technical Information

P.O. Box 62, Oak Ridge, TN 37831

Prices available from (423) 576-8401

http://apollo.osti.gov/bridge/

Available to the public from the National Technical Information Service

U.S. Department of Commerce 5285 Port Royal Rd., Springfield, VA 22161

http://www.ntis.gov/

OR

Lawrence Livermore National Laboratory Technical Information Department's Digital Library http://www.llnl.gov/tid/Library.html 


\section{Explosive Effectiveness Capability (ExEC)}

\section{Glen Nakafuji (nakafuji1@Ilnl.gov), Lara Daily(daily4@llnl.gov), and Jim Leake}

Gaining accurate predictions of damage inflicted by high explosive devices is vital in order to minimize collateral damage effects on a target. ExEC provides a means for conducting very detailed analysis of weapons effects on targets for advanced mission planning purposes. ExEC is composed of a suite of high fidelity physics codes, which have been used for decades by the nuclear weapons laboratories for assessing high explosive, thermal, and structural effects. The ExEC capability should not be confused with the fast running empirical codes MEA and MEVA, which are good for fast scoping analysis. MEA and MEVA rely on look-up tables or simple approximations to quickly obtain a rough estimate of weapon damage on a target. In contrast, the ExEC capability provides a much higher fidelity damage prediction and a limitless number of target configurations by solving the time dependent conservation equations for mass, momentum, and energy, in order to directly simulate the interaction of a weapon with a target component. In contrast, MEA/MEVA must be calibrated for every different weapon type and target.

ExEC has produced accurate simulations for weapon disablement, shape charge penetration, sympathetic detonation, fragment damage effects, and blast effects. For example, ExEC was used to look at a DTRA test performed at White Sands Missile Range, Dipole Orbit 1 (DO1). In DO1, a BLU-109 bomb was statically detonated in a partially buried four-room building that was storing chemical and biological weapon simulants, as well as inactive equipment typical of a CBW (Chemical and Biological Warfare) facility. The blast wave (overpressure) histories were recorded and compared to an ExEC and MEVA simulation. A direct comparison between experimental data and calculations, for a single pressure gauge, indicated that MEVA had a $200 \%$ error compared to 5\% for ExEC. In addition, ExEC tracks the time dependant fluctuations in pressure (for an accurate prediction of the impulse), while MEVA produces only the peak overpressure.

ExEC provides added flexibility in target configurations, weapon selection, and weapon placement. For each potential target, ExEC can look into a variety of possible scenarios, in great detail, that will bound the uncertainty in achieving a mission goal. This is a great advantage on targets where it is desirable to minimize collateral damage. ExEC can provide detailed shot maps of ideal weapon placement for achieving target kill most efficiently. To do this ExEC requires more detailed information than a typical MEVA analysis. 
ExEC leverages an existing pool of knowledge from the nuclear weapons analysis community in the subjects of explosives, fluid dynamics, and structural response, as well and the computational resources of the DOE ASCI Program. ASCI is a high performance computing initiative to enable tera-scale computing for Stockpile Stewardship analysis into 2010. In a current listing of the top 500 fastest supercomputers in the world (from top500.org) the top three computers were ASCI machines from the three DOE National Labs: Lawrence Livermore, Los Alamos, and Sandia. This capability enables ExEC to perform very detailed calculations on the order of a few days that would take a few hundred days on a Cray supercomputer. 